\title{
Viral expression directs the fate of $B$ cells in BLV-infected sheep
}

\author{
Arnaud Florins ${ }^{1 *}$, Amel-Baya Bouzar ${ }^{1}$, Alix Debrogniez ${ }^{1}$, Carole François ${ }^{1}$, Michal Reichert ${ }^{2}$, Luc Willems ${ }^{1,3}$ \\ From 15th International Conference on Human Retroviruses: HTLV and Related Viruses \\ Leuven and Gembloux, Belgium. 5-8 June 2011
}

There is a long lasting debate about the latency of human T-lymphotropic virus type 1 (HTLV-1) and bovine leukemia virus (BLV). Evidence indicates that these viruses are transcriptionally silent and replicate through mitotic division of infected cells (clonal expansion). However, this model is inconsistent with the permanent and vigorous stimulation of the host immune response directed against these viruses.

To address this apparent paradox, we studied the fate of cells in which viral expression was transiently induced. Using a dual fluorochrome labeling approach, we show that virus-positive and negative cell populations have different kinetics in BLV-infected sheep. Furthermore, cyclosporine treatment completely abrogates the difference in kinetics, consistent with a role of the immune response in controlling virus expressing cells.

\footnotetext{
Author details

${ }^{1}$ Cellular and molecular biology, Gembloux Agro-Bio Tech, University of Liège, Gembloux, Belgium. ${ }^{2}$ National Veterinary Research Institute, Pulawy, Poland. ${ }^{3}$ Interdisciplinary Cluster for Applied Genoproteomics, University of Liège, Liège, Belgium.
}

Published: 6 June 2011

\footnotetext{
* Correspondence: afflorins@ulg.ac.be

${ }^{1}$ Cellular and molecular biology, Gembloux Agro-Bio Tech, University of Liège, Gembloux, Belgium

Full list of author information is available at the end of the article
}

Submit your next manuscript to BioMed Central and take full advantage of:

- Convenient online submission

- Thorough peer review

- No space constraints or color figure charges

- Immediate publication on acceptance

- Inclusion in PubMed, CAS, Scopus and Google Scholar

- Research which is freely available for redistribution 